\title{
A Research on Psychological Well Being and Job Performance of Employees in Msme in Coimbatore District
}

\author{
B. Shanmugam, R. Ganapathi
}

\begin{abstract}
Psychological well being is highly related to outcomes of personal life and work and it is subjective in nature and if individuals are well psychologically, they will be themselves to be. Demands to enhance psychological well being of employees are growing because it is essential for them to perform well in their jobs. Significant difference prevails among psychological well being and profile of employees of MSME except for gender. Environmental mastery, self-acceptance, purpose in life and positive relation with others have positive and significant influence on job performance of employees in MSME. In order to improve psychological well being of employees in MSME, they should be happy with things driven out and must ready to change many things about themselves and also they should accomplish their duties and responsibilities efficiently. Besides, they should get many things from friends though maintaining better relationship with them and they must be very clear about their direction and purpose of their life.
\end{abstract}

Key Words- Employees, Job Performance, MSME, Psychological Well Being

\section{INTRODUCTION}

Micro, small and medium enterprises (MSMEs) in India is an exceedingly critical in achieving objectives of nation through connecting urban rural division, decreasing poverty and providing employment to million of people and they have very significant role in socio-economic transformation of India. The MSME sector in India is diversified in nature in size, products, services and adoption of technologies. Indian MSMEs consist of 80 per cent of total number of industrial units and generate more than 8000 value added products. The growth of MSMEs and ratio of labour to capital is higher in comparison with large scale industries.

Psychological well being is typically a combination of hedonic and eudaimonic perspectives and it is all about live going smooth and well and it combines good feelings and effectual functioning of individuals. Thus, people with high level of psychological well being are highly pleased, competent, performed well in their words and satisfied with life. Psychological well being is highly related to outcomes of personal life and work and it is subjective in nature and if individuals are well psychologically, they will be themselves to be and it also affects their job performance. The work place is an inseparable part in life of employees that impacts their life and well being of community. The

Revised Manuscript Received on April 12, 2019.

B. Shanmugam, MBA., MHRM., M.Phil., Ph.D. (Part-Time) Research Scholar, AMET Business School, Academy of Maritime Education and Training (AMET), Chennai. Pin Code - 603 112, Tamil Nadu State. India.

Dr. R. Ganapathi, M.Com., MBA (Finance)., MBA (HR)., M.Phil., Ph.D., PGDCA. Assistant Professor, Directorate of Distance Education, Alagappa University, Karaikudi. Pin Code - 630 003. Tamil Nadu State. India. E-mail: meenaramganapathi@gmail.com employees possessing high degree of psychological well being are highly cooperative and efficient and are having long term association with their organizations.

Demands to enhance psychological well being of employees are growing because it is essential for them to perform well in their jobs. Coimbatore district is an industrial hub for micro, small and medium enterprises (MSMEs) in Tamil Nadu and it has more than 50000 MSMEs in various fields and it provides huge employment opportunities for both skilled and unskilled people in manufacturing sector. Hence, it is very important to study psychological well being and job performance of employees in MSME in Coimbatore district.

\section{REVIEW OF LITERATURE}

Reddy (2012) revealed that significant difference was there among psychological well beings and efficacy of women employees. In addition, performance of women employees was significantly related with their psychological well beings. Kaur (2013) concluded that psychological well being helped employees to do their jobs better and it improved self confidence, competency, team work, morality, efficiency, productively, services, interpersonal relation and commitment of employees towards organizations. Emerald and Genevieve (2014) showed that dimensions of psychological well beings were positively and significantly related with job performance of employees.

Nielsen et al (2017) revealed that significant difference was there among well beings of employees and performance of organization, while, there was significant relation among well beings of employees and their performance. Nangov et al (2018) concluded that psychological capital influenced work welling and job performance of employees and components of psychological well beings were influencing job performance among employees.

\section{OBJECTIVES OF THE STUDY}

1. To study psychological well being of employees in MSME.

2. To inspect difference among profile of employees of MSME and their psychological well being.

3. To analyze influence of dimensions of psychological well being on job performance of employees in MSME. 


\section{HYPOTHESES OF THE STUDY}

1. There is no significant difference among psychological well being and profile of employees of MSME.

2. There is no significant influence of dimensions of psychological well being on job performance of employees in MSME.

\section{METHODOLOGY}

The present research is done in Coimbatore district. Employees of MSME are chosen by using simple random sampling method and structured questionnaire is used to gather data from 300 employee of MSME. Percentages are computed to understand profile of employees of MSME and mean and standard deviation are worked out to examine dimensions of psychological well being of employees in MSME. t-test and F-test are done to inspect difference among profile of employees of MSME and their psychological well being. Multiple regression analysis is used to analyze influence of dimensions of psychological well being on job performance of employees in MSME.

\section{RESULTS AND DISCUSSION}

\subsection{PROFILE OF EMPLOYEES}

The profile of employees of Micro, Small and Medium Enterprises (MSME) is given in Table-1. The findings disclose that 62.67 per cent of employees are males, whilst, 37.33 per cent of them are females and 28.67 per cent of them come under age category of $31-35$ years, whilst, 9.33 per cent of them come under age category of $41-45$ years. The findings explain that 32.33 per cent of them hold higher secondary, whilst, 21.33 per cent of them hold under graduation and 52.00 per cent of them are workers, whilst, 16.67 per cent them are managers.

Table-1. Profile of Employees of Micro, Small and Medium Enterprises

\begin{tabular}{|l|c|c|}
\hline \multicolumn{1}{|c|}{ Profile } & Number of Teachers & Percentage \\
\hline Gender & 188 & \\
\hline Male & 112 & 62.67 \\
\hline Female & & 37.33 \\
\hline Age Category & 37 & 12.33 \\
\hline $21-25$ Years & 69 & 23.00 \\
\hline $26-30$ Years & 86 & 28.67 \\
\hline $31-35$ Years & 80 & 26.67 \\
\hline $36-40$ Years & 28 & 9.33 \\
\hline $41-45$ Years & & \\
\hline Education & 91 & 23.67 \\
\hline Secondary & 68 & 22.33 \\
\hline Higher Secondary & 64 & 21.33 \\
\hline Diploma & & \\
\hline Graduation & 50 & 16.67 \\
\hline Designation & 94 & 31.33 \\
\hline Manager & 156 & 52.00 \\
\hline Supervisor & 53 & 17.67 \\
\hline Worker & 103 & 34.33 \\
\hline Work Experience & & \\
\hline $1-5$ Years & & \\
\hline $6-10$ Years & & \\
\hline
\end{tabular}

\begin{tabular}{|l|c|c|}
\hline $11-15$ Years & 95 & 31.67 \\
\hline $16-20$ Years & 49 & 16.33 \\
\hline Monthly Income & & 24.00 \\
\hline $\begin{array}{l}\text { Less than } \\
\text { Rs.20,000 - }\end{array}$ & 72 & 29.67 \\
$\begin{array}{l}\text { Rs.20,001 } \\
\text { Rs.25,000 }\end{array}$ & 69 & 21.67 \\
\hline $\begin{array}{l}\text { Rs.25,001 } \\
\text { Rs.30,000 }\end{array}$ & 43 & 14.33 \\
\hline $\begin{array}{l}\text { Rs.30,001 than } \\
\text { Rs.35,000 }\end{array}$ & 31 & 10.33 \\
\hline $\begin{array}{l}\text { More } \\
\text { Rs.35,000 }\end{array}$ & \\
\hline
\end{tabular}

The findings make clear that 34.33 per cent of them are bearing $6-10$ years of work experience, whilst, 16.33 per cent of them are bearing $16-20$ years of work experience and 29.67 per cent of them are earning monthly income of Rs.20,001 - Rs.25,000, whilst, 10.33 per cent of them are earning monthly income of more than Rs.35,000.

\subsection{DIMENSIONS OF PSYCHOLOGICAL WELL BEING OF EMPLOYEES IN MSME}

The dimensions of psychological well being of employees in MSME were studied and the results are given as below.

\subsubsection{SELF-ACCEPTANCE}

The self-acceptance of employees in MSME is given in Table-2.

Table-2. Self-Acceptance

\begin{tabular}{|l|c|c|}
\hline \multicolumn{1}{|c|}{ Self-Acceptance } & Mean & $\begin{array}{c}\text { Standard } \\
\text { Deviation }\end{array}$ \\
\hline I am confident and optimistic & 3.86 & 0.85 \\
\hline I like all features of my character & 3.79 & 0.99 \\
\hline $\begin{array}{l}\text { I am happy about things have driven } \\
\text { out }\end{array}$ & 3.34 & 1.03 \\
\hline $\begin{array}{l}\text { I get many things out of life as } \\
\text { compared to I have }\end{array}$ & 3.83 & 0.87 \\
\hline $\begin{array}{l}\text { I like to change many things about } \\
\text { myself }\end{array}$ & 3.31 & 1.01 \\
\hline
\end{tabular}

The employees of MSME are agreed with they are confident and optimistic, they like all features of their characters and they get many things out of life as compared to they have, while, they are neural with they are happy about things have driven out and they like to change many things about themselves.

\subsubsection{ENVIRONMENTAL MASTERY}

The environmental mastery of employees in MSME is given in Table- 3 .

Table-3. Environmental Mastery

\begin{tabular}{|l|c|c|}
\hline \multicolumn{1}{|c|}{ Environmental Mastery } & Mean & $\begin{array}{c}\text { Standard } \\
\text { Deviation }\end{array}$ \\
\hline $\begin{array}{l}\text { I am responsible for the condition of } \\
\text { my life }\end{array}$ & 3.90 & 0.86 \\
\hline
\end{tabular}




\begin{tabular}{|l|c|c|}
\hline $\begin{array}{l}\text { I am able to manage various } \\
\text { responsibilities in my life }\end{array}$ & 3.88 & 0.85 \\
\hline $\begin{array}{l}\text { I am regularly overwhelmed by my } \\
\text { responsibilities }\end{array}$ & 3.29 & 0.97 \\
\hline $\begin{array}{l}\text { I am efficiently managing time to } \\
\text { carry out my duties }\end{array}$ & 3.85 & 0.98 \\
\hline $\begin{array}{l}\text { All my efforts to find various actions } \\
\text { and relations are fairly successful }\end{array}$ & 3.76 & 0.89 \\
\hline
\end{tabular}

The employees of MSME are agreed with they are responsible for the condition of their life, they are able to manage various responsibilities in their life, they are efficiently managing time to carry out their duties and all their efforts to find various actions and relations are fairly successful, while, they are neutral with they are regularly overwhelmed by their responsibilities.

\subsubsection{POSITIVE RELATION WITH OTHERS}

The positive relation with others of employees in MSME is given in Table-4.

Table-4. Positive Relation with Others

\begin{tabular}{|l|c|c|}
\hline \multicolumn{1}{|c|}{ Positive Relation with Others } & Mean & $\begin{array}{c}\text { Standard } \\
\text { Deviation }\end{array}$ \\
\hline $\begin{array}{l}\text { People generally look me as } \\
\text { affectionate and loving }\end{array}$ & 3.70 & 0.69 \\
\hline $\begin{array}{l}\text { I enjoy personal relation with my } \\
\text { friends and family }\end{array}$ & 3.73 & 0.65 \\
\hline $\begin{array}{l}\text { I am a good listener when my friends } \\
\text { discuss their problems with me }\end{array}$ & 3.62 & 0.81 \\
\hline $\begin{array}{l}\text { People usually depict me as a helping } \\
\text { and ready to share my time with others }\end{array}$ & 3.66 & 0.71 \\
\hline $\begin{array}{l}\text { I get many things from my friendships } \\
\text { with others }\end{array}$ & 3.37 & 1.01 \\
\hline
\end{tabular}

The employees of MSME are agreed with people generally look them as affectionate and loving, they enjoy personal relation with their friends and family, they are good listener when their friends discuss their problems with them and people usually depict them as a helping and ready to share their time with others, while, they are neutral with they get many things from their friendships with others.

\subsubsection{PURPOSE IN LIFE}

The purpose in life of employees in MSME is given in Table-5.

Table-5. Purpose in Life

\begin{tabular}{|l|c|c|}
\hline \multicolumn{1}{|c|}{ Purpose in Life } & Mean & $\begin{array}{c}\text { Standard } \\
\text { Deviation }\end{array}$ \\
\hline $\begin{array}{l}\text { I have clear idea about purpose and } \\
\text { direction of my life }\end{array}$ & 3.40 & 0.86 \\
\hline $\begin{array}{l}\text { I like to concentrate on present life not } \\
\text { future }\end{array}$ & 3.80 & 1.01 \\
\hline $\begin{array}{l}\text { I am actively involved to carry out } \\
\text { plans for myself }\end{array}$ & 3.74 & 0.92 \\
\hline $\begin{array}{l}\text { I am happy with what I achieve so far } \\
\text { in my life }\end{array}$ & 3.72 & 0.98 \\
\hline $\begin{array}{l}\text { I am happy about what I did in past } \\
\text { and what I will do in future }\end{array}$ & 3.39 & 0.97 \\
\hline
\end{tabular}

The employees of MSME are agreed with they like to concentrate on present life not future, they are actively involved to carry out plans for themselves and they are happy with what they achieve so far in their life, while, they are neutral with they have clear idea about purpose and direction of their life and they are happy about what they did in past and what they will do in future.

\subsection{PROFILE OF EMPLOYEES OF MSME AND PSYCHOLOGICAL WELL BEING}

To inspect difference among profile of employees of MSME and psychological well being, t-test and ANOVA test are done and the results are given in Table-6.

Table-6. Difference among Profile of Employees of MSME and Psychological Well Being

\begin{tabular}{|c|c|c|}
\hline Particulars & $\begin{array}{l}\text { t-Value / } \\
\text { F-Value }\end{array}$ & Sig \\
\hline $\begin{array}{l}\text { Gender and Psychological Well } \\
\text { Being }\end{array}$ & $\begin{array}{c}0.209 \\
\text { (t-value) }\end{array}$ & .834 \\
\hline $\begin{array}{l}\text { Age Category and Psychological } \\
\text { Well Being }\end{array}$ & $\begin{array}{l}4.618^{* *} \\
\text { (F-value) }\end{array}$ & .000 \\
\hline $\begin{array}{l}\text { Education and Psychological } \\
\text { Well Being }\end{array}$ & $\begin{array}{l}4.426^{* *} \\
\text { (F-value) }\end{array}$ & .000 \\
\hline $\begin{array}{l}\text { Designation and Psychological } \\
\text { Well Being }\end{array}$ & $\begin{array}{l}4.572^{* *} \\
\text { (F-value) }\end{array}$ & .000 \\
\hline $\begin{array}{lll}\text { Work } & \text { Experience } & \text { and } \\
\text { Psychological Well Being } & \\
\end{array}$ & $\begin{array}{l}7.931^{* * *} \\
\text { (F-value) }\end{array}$ & .000 \\
\hline $\begin{array}{lll}\text { Monthly Income } & \text { and } \\
\text { Psychological Well Being } & \end{array}$ & $\begin{array}{l}4.985^{* *} \\
\text { (F-value) }\end{array}$ & .000 \\
\hline
\end{tabular}

The F-values are explicating that significant difference exits among psychological well being and profile of employees of MSME excluding gender at one cent level. Accordingly, the null hypothesis is not accepted.

\subsection{INFLUENCE OF DIMENSIONS OF PSYCHOLOGICAL WELL BEING ON JOB PERFORMANCE OF EMPLOYEES IN MSME}

To analyze influence of dimensions of psychological well being on job performance of employees in MSME, multiple regression analysis is used and the results are given in Table- $7 . \mathrm{R}^{2}$ and adjusted $\mathrm{R}^{2}$ are 0.55 and 0.53 that imply the regression model has good fit and independent variables altogether have 53 per cent of variation on dependent variable. The F-value of 17.551 explains the model is significant at one per cent level.

Table-7. Influence of Dimensions of Psychological Well Being on Job Performance of Employees in MSME

\begin{tabular}{|l|c|c|c|}
\hline $\begin{array}{c}\text { Dimensions of } \\
\text { Psychological Well Being }\end{array}$ & $\begin{array}{c}\text { Regression } \\
\text { Coefficients }\end{array}$ & $\begin{array}{c}\text { t- } \\
\text { value }\end{array}$ & Sig \\
\hline Constant & $8.379^{* * *}$ & 19.258 & .000 \\
\hline Self-Acceptance $\left(\mathrm{X}_{1}\right)$ & $.867^{* *}$ & 7.564 & .000 \\
\hline Environmental Mastery $\left(\mathrm{X}_{2}\right)$ & $.984^{* *}$ & 8.145 & .000 \\
\hline $\begin{array}{l}\text { Positive Relation with } \\
\text { Others }\left(\mathrm{X}_{3}\right)\end{array}$ & $.712^{* *}$ & 6.936 & .000 \\
\hline
\end{tabular}




\begin{tabular}{|c|c|c|c|}
\hline Purpose in Life $\left(\mathrm{X}_{4}\right)$ & $.790^{* *}$ & 7.102 & .000 \\
\hline $\mathrm{R}^{2}$ & 0.55 & - & - \\
\hline Adjusted R & 0.53 & - & - \\
\hline $\mathrm{F}$ & 17.551 & - & .000 \\
\hline
\end{tabular}

Significant at $1 \%$ level

The findings elucidate that environmental mastery, selfacceptance, purpose in life and positive relation with others are significantly and positively influencing job performance of employees in MSME at one per cent level. As an outcome, the null hypothesis is not accepted.

\section{CONCLUSION}

The findings of this study reveal that significant difference prevails in psychological well being among profile of employees of MSME except for gender. Environmental mastery, self-acceptance, purpose in life and positive relation with others have positive and significant influence on job performance of employees in MSME. In order to improve psychological well being of employees in MSME, they should be happy with things driven out and must ready to change many things about themselves and also they should accomplish their duties and responsibilities efficiently. Besides, they should get many things from friends though maintaining better relationship with them and they must be very clear about their direction and purpose of their life and they should be happy with past things and plan and work well in order to achieve their objectives in future life.

\section{REFERENCES:}

1. Jaideep Kaur.(2013). Role of psychological well being and its impact on the motivational level of the employees in IT sector. International Journal of Advanced Research in Management and Social Sciences, 2(6), 43-51.

2. Jayashankar Reddy, K.(2012). A comparative study of selfefficacy and subjective well-being among employed women and unemployed women. International Journal of Research in Commerce, IT \& Management, 2(8),54-58.

3. Karina Nielsena, Morten B. Nielsen, Chidiebere Ogbonnaya, Marja Kansala, Eveliina Saari, \& Kerstin Isaksson.(2017). Workplace resources to improve both employee well-being and performance: A systematic review and meta-analysis. Work and Stress, 10, 1-21.

4. Rizal Nangov, Sasmoko, \& Yasinta Indrianti.(2018). Psychological capital, work well-being, and job performance. International Journal of Engineering \& Technology, 7 (4), 6365

5. Trecy Emerald, \& Genoveva.(2014). Analysis of psychological well-being and job satisfaction toward employees performance in Pt Aristo Satria Mandiri Bekasi, Indonesia. International Journal of Business, Economics and Law, 4(1), 22-30. 